\title{
THE IMPACT OF CORPORATE SOCIAL RESPONSIBILITY ON EMPLOYEE'S JOB SATISFACTION
}

\author{
Soran K. Omer \\ Department of Administration and Accounting, Faculty of Humanities and Social \\ Sciences, Koya University, Koya KOY45, Kurdistan Region - F.R. Iraq. \\ soran.kakarash@koyauniversity.org
}

\section{Original Scientific Paper doi:10.5937/jouproman6-18296}

\begin{abstract}
This study purposes at examining the impact of corporate social responsibility (CSR) on employee job satisfaction, it is an exploratory study about employee's opinion toward CSR activities of Paky hospital.
\end{abstract}

The CSR is the independent variable and employee's job satisfaction is the dependent variable.

This study also aims of check the availability of CSR activities and evaluates its effect in the hospital.

A questionnaire involving of eight items and has been set and distributed among the employees of Paky hospital randomly. We have used OneSample Statistics t-test and ANOVA with the program SPSS.v.20 to test the validity of our hypothesis.

The main conclusion of the study is there has the insignificant effect of CSR activities on job satisfaction of employees in Paky hospital; as well some of the elements or activities of CSR and job satisfaction are shared in the hospital.

Keywords: CSR, Job satisfaction, employees, hospitalization, responsibility, satisfaction

\section{Introduction}

\subsection{Research problem}

Engaging in CSR has become more important to all stakeholders and has also become a large part of companies' business and reporting. By being informative about the good work it may attract customers, investors and talent. The CSR reports are mostly for customers and investors while employees' knowledge is not prioritized. This is why we chose to investigate the impacts of CSR activities on employee's job satisfaction.

\subsection{Research objectives}

Utilizing their CSR efforts, companies can enable opportunities not only to increase brand awareness and strengthen their relationship with suppliers and government bodies, but also to influence their employee's job satisfaction. As well as, this study aims to understand the multifaceted influences of CSR activities on employee's job satisfaction. Therefore, the research objectives are as follows:

1. To identify the impact of CSR activities on employee's job satisfaction at Paky hospital.

2. To study the presence of CSR activities at Paky hospital.

3. To study the effect of CSR activities on employee's job satisfaction at Paky hospital. 
4. To evaluate the effect of the corporate social responsibility on employee's job satisfaction at Paky hospital.

\subsection{Importance of the research}

The importance of the study is that the study attempts to recognize the impacts of corporate social responsibilities of Paky Hospital on employee's satisfaction. And this study can point out the strengths and weaknesses of the board of directors, as well as CEOs of the hospital from side to side CSR.

\subsection{Research methods}

Studying is based on qualitative analytical method is used for gathering information in this study to approach the accurate results the data is analyzed using one sample t-test and ANOVA at statistical program called SPSS.

The theoretical framework consists of the definition on the concepts of both CSR and job satisfaction. In the study CSR is the independent variable; and job satisfaction is the dependent variables. A literature review follows.

\subsection{Research question}

There are some questions that researchers try to get answers through this study which including:

1- What are the effects of CSR on employee's job satisfaction in Paky hospital?

2- Which components of CSR are more effective on employee's job satisfaction?

3- Which levels of management are more satisfied by CSR activities of the hospital?

\subsection{Research hypotheses}

\section{First hypotheses:}

H1. There is a positive effect of corporate social responsibility on job satisfaction.

H0. There is no effect of corporate social responsibility on job satisfaction.

\section{Second hypotheses:}

H1. All components of CSR have huge impact on job satisfaction for Paky hospital and vice versa.

H0. Not all levels of management may be satisfied by CSR components in the hospital and vice versa

\subsection{Case presentation}

We have consciously chosen the Paky Hospital for this study which is located at Erbil governorate and it's the capital of Iraqi Kurdistan Region. While it will to giving health services, but it will effort to maximize profit and wealth maximization. At that time, this hospital managed by the board and CEO, so that they has a great responsibility and to balance it between stockholders, employees and environment. But we focused on employee's job satisfaction. 


\subsection{Important definitions}

In general, CSR refers to company activities voluntary by definition demonstrating the inclusion of social and environmental concerns in business operations and in interactions with stakeholders. However, job satisfaction is one of the most widely studied and measured constructs in the organizational behavior and management literature. Interest in job satisfaction proceeds from its relationships to other substantial organizational outcomes including absenteeism, organizational commitment, turnover, and performance. Moreover, the current environment with it's extremely unstable an organizational change.

Furthermore, job satisfaction is an important issue for employees and companies. Outcome variables such as absenteeism and organizational inefficiency, counterproductive behavior and sabotage are consequences of low job satisfaction. On the other hand, variables such as job autonomy, satisfaction with pay, training and integration lead to higher job satisfaction.

\section{Literature reviews}

\section{1 (CSR) concepts and definition}

"CSR is approached as a modern concept and a business practice which is discussed conceptually in philosophic discussions and also is grounded on 19th century philanthropic activities. And it is also accepted as a concept, apart from some classifications, that includes the issue of how the managers must handle the public policy and social issues" (Yapar, 2017).

According to Shuli and Suwandee (2017) CSR is a concept that attracts all over the world's attention and acquires a new resonance in the global economy. Since last 60 years ago, CSR has been taking place for a long debate. From that time on the terminology was shifted from the social responsibility of business to CSR. Additionally, CSR contains a great spread of approaches, theories and terminologies (Shuli and Suwandee, 2017).

CSR is an essential point of corporate to make our society prosperous and stable. Corporates are faced of increasing pressure to proceed socially responsive behaviors from their stakeholders which including shareholders, investors, managers, employees, and consumers. Therefore, an increasing number of organizations have realized the importance and benefits of practicing CSR. CSR enables the corporates to give back to their stakeholders and goes further their business interests (Shuli and Suwandee, 2017). As well as, Hameed (2010) focused that there are four components of CSR consist of economic responsibility, legal responsibility, ethical responsibility and philanthropic responsibility (Hameed, 2010).

"Furthermore, by improving the parts of a system individually, CSR may not be improved, and most likely will not be improved according to the proposed definition. When applying the concepts of systems thinking to CSR, corporations are able to meet the demands of society and their stakeholders. The exclusion of systems thinking is unique and a departure from other scholarly and professional works on the subject. Commonly, CSR activities are viewed as distinct parts (e.g. social, economic, environmental, stakeholder) or as linear relationships rather than as an interrelated process" (Smith, 2011). 
Also Hameed (2010) dedicated that CSR can be used as a tool for companies to implement in their strategy and can improve public relation and economic performance. On the other hands,

Håkansson and O’Neill (2016) defined CSR That CSR refer to company activities voluntary by definition demonstrating the inclusion of social and environmental concerns in business operations and in interactions with stakeholders.

Additionally, Macuda (2016) pointed that there are five different dimensions concerning social responsibility in hospitals:

1. Leadership and inner processes which include the areas of mission and vision, policies and procedures, ethical codes and regulations.

2. Marketing that refers to suppliers and contractors, supply chain, consumer rights, responsibilities and liability management services including responsible purchasing.

3. Workplace environment which contains staff safety and health issues.

4. Environment which includes issues of sustainable development, pollution, waste management, energy saving and green purchasing management.

5. Community that states the local community, academic community in partnership with social institutions, partnership with Non-Governmental Organizations (NGOs), volunteer participation supporting activities of employee and charitable support.

\subsection{Job satisfaction concepts and definition}

"Job satisfaction is a general expression of staff's positive attitudes built up to their jobs. Job satisfaction has been a subject to scientific researches with "Hawthorn" studies in 20th centuries. And it is defined as pleasurable or positive emotional state as a result of assessment of the job (Çelik, 2011) at the same time job satisfaction has been defined as an agreeable emotional state, consequent from the appraisal ones job experiences, as well as the point to which the employees expresses a positive affective positioning toward a job." (Walker and Sorce, 2009)

In addition, Neog and Bara (2014) "pointed that there are many factors which influenced employees job satisfaction and it's clear that has a positive and strong correlation between working environment and job satisfaction." Furthermore, Shareef, V. A., Husien, A. H., and Omer, S. K. (2018) "focused on job satisfaction that it can see as an occupation of the features of a job, view of others, and employee's personality."

"Moreover the physical work environment has a great impact on their level of satisfaction. Subjects associated to comfort, communication, access and functional efficiency, taken together, were mentioned three times more than a frequently than were compensation, work hours and benefits or management. On the other hands the role of interior design consultant is critical to the improvement of an effective environment. The quintessential office cannot be created without simultaneously designing physical, technical, social and organizational systems that are in harmony" (Shareef, V. A., Husien, A. H., and Omer, S. K. 2018, 2). 
In addition, job satisfaction is "an affective reaction to one's job typically argued to be a function of situational factors, including the nature of work, human resources elements and the organizational environment" (Boswell, W.R., Shipp, A.J., Payne, S.C., \& Culbertson, S.S.,2009, 9). There is a difference between intrinsic job satisfaction and extrinsic job satisfaction. Intrinsic job satisfaction means that factors of doing the job itself e.g. recognition, achievement and responsibility induce job satisfaction. It tends to be quite similar when there is a change of occupation and/or employer. Extrinsic job satisfaction means that environment-related factors e.g. company policies and practices, salary and interpersonal relations in supervision induce job satisfaction. And People tend to have some stability in the level of job satisfaction, but factors can lead it to a higher or lower level. One of those factors is the newness of the job. Correspondingly, feelings about a job vary in accordance to change in a function of a job, which suggests a predictable pattern of an initial peak and a following decline in job satisfaction when you start a new job. Even when people change their job they often stay in their own occupation or find $\mathrm{a}$ job in a related occupation, which means that certain organizational conditions that cause job satisfaction such as job content and job stressors remain constant.

\section{Data Analysis \& Discussion}

\subsection{Data collection \& findings}

The questionnaires were distributed among 25 employees were $61 \%$ males and $39 \%$ females in the Paky hospital as appears in table (3.1).

Table (3.1 ) Gender sample

\begin{tabular}{|c|c|c|}
\hline Sex & Frequency & Percentage \\
\hline Male & 12 & 48 \\
\hline Female & 13 & 52 \\
\hline
\end{tabular}

The sample is according to age of employees, which is divided into five classes from 20-29 years, 30-39 years, 4049 years for each class there is the number of participations with their ratios shown in the table (3.2) as below:

Table (3.2) age sample

\begin{tabular}{|c|c|c|}
\hline Age classes & Frequency & Percentage \\
\hline less than 20 years & 1 & 1.8 \\
\hline 20-29 years & 17 & 29.8 \\
\hline 30-39 years & 6 & 10.5 \\
\hline 40-49 years & 1 & 1.8 \\
\hline
\end{tabular}


The sample is also arranged according to years of work experience of employees which is divided into six classes (less than year, 1-5 years, 6-10 years, also for each class it has the number of participants with their ratios that is shown in the table (3.3) bellow:

Table (3.3) Work experience classes

\begin{tabular}{|c|c|c|}
\hline Experience classes & Frequency & Percentage \\
\hline less than a year & 7 & 12.3 \\
\hline $1-5$ years & 16 & 28.1 \\
\hline 6 - 10 years & 2 & 3.5 \\
\hline
\end{tabular}

3.2 Interview questions and the Questionnaire form content (Study Tools)

The researcher used interviews and questionnaire tool see appendixes (B\&C), to measure the CSRs dimensions and attributes at the Paky hospital and the researcher developed depending on the side of theoretical study and previous studies on CSR and job satisfaction.

There are seven questions for the interviews about CSR; directed to the relevant managers of Paky hospital (As a Study tool).Correspondingly, the questionnaire is involved in the initial image on 3 pages and (8) phrases and each of them is given weight listed,

In addition, using one sample t-test for CSR activities in Paky hospital as well table (3.4) shows that all of the elements or activities of CSR and job satisfaction are common in Paky hospital that were obtained by using mean and std. deviation and (t.3 p <0.05 level ). Correspondingly, the most attractive activities of CSR was (CSR activate - Q2) which is expressing of the question "Do they think that CSR is Its important?" because of the it has greater rate of mean (4.3200 P. .000). On the other hands the poorer elements is the employees aware of the CSR? att the hospital with mean rate $(\mathrm{M}=3.0000, \mathrm{P}$ 1.000). Then their tests for 3rd and 4th hypothesis which are related with all components of corporate social responsibility have huge impact on job satisfaction for Paky hospital and vice versa. Also at 4th hypothesis has all levels of management may be satisfied by corporate social responsibility components in the hospital and vice versa. 
(JPMNT) Journal of Process Management - New Technologies, International

Vol. 6, No 3, 2018.

Table 3.4 One-sample t-test for CSR and Job satisfaction in Paky Hospital

\begin{tabular}{|c|c|c|c|c|c|c|}
\hline \multicolumn{1}{|c|}{ CSR activities } & $\mathbf{N}$ & Mean & Std. Deviation & $\mathbf{t}$ & Df & Sig. (2-tailed) \\
\hline CSR activity -Q1 & 25 & 3.0000 & .86603 & .000 & 24 & 1.000 \\
\hline CSR activity - Q2 & 25 & 4.3200 & 1.06927 & 6.172 & 24 & .000 \\
\hline JobSatisfactionQ1 & 25 & 3.4400 & .91652 & 2.400 & 24 & .024 \\
\hline JobSatisfactionQ2 & 25 & 3.5200 & .82260 & 3.161 & 24 & .004 \\
\hline JobSatisfactionQ3 & 25 & 3.1200 & .97125 & .618 & 24 & .543 \\
\hline JobSatisfactionQ4 & 25 & 3.1600 & 1.06771 & .749 & 24 & .461 \\
\hline JobSatisfactionQ5 & 25 & 3.8000 & 1.00000 & 4.000 & 24 & .001 \\
\hline JobSatisfactionQ6 & 25 & 3.6400 & 1.28712 & 2.486 & 24 & .020 \\
\hline
\end{tabular}

*Item is significant at t.3 $\mathrm{p}>0.05$ level (2-tailed).

On the other hand to test first question and according to one way analysis of variance (ANOVA) of CSR activities and job satisfaction ranges $(\mathrm{F}=4.154, \mathrm{P} .010)$ that shown in the Table (3.5), that's point to insignificant effect of CSR activities on job satisfaction of employees in Paky hospital due to test first and second hypothesis.

Table3.5 One way analysis of variance (ANOVA) of CSR and Job satisfaction

\begin{tabular}{|c|c|c|c|c|c|}
\hline & $\begin{array}{c}\text { Sum of } \\
\text { Squares }\end{array}$ & df & $\begin{array}{c}\text { Mean } \\
\text { Square }\end{array}$ & F & Sig. \\
\hline Between Groups & 186.682 & 5 & 37.336 & 4.154 & .010 \\
Within Groups & 170.758 & 19 & 8.987 & & \\
Total & 357.440 & 24 & & & \\
\hline
\end{tabular}

*Item is significant $\mathrm{p}<0.05$.

However, according to interviews about CSR; directed to the relevant managers of Paky Hospital, most of managers have a positive expression with responsibility to the question about hospital responsibility for providing the wellbeing of the society customers, at the same time, according to the CSR activities the manager's focus on Paky card of the health insurance. 
Correspondingly, according to managers spokes they are spent 20000 US \$ to the CSR activities, in addition, some of the manager feel that CSR programs has a positive impact on profits, but others do not reflect. As well as some of managers think that the social responsibility program has an effect on marketing; also others believe it has an impact on this famously, lastly all managers think that the employees of Paky are aware CSR activities.

In addition, there is some information at 2017 that intensive on CSR activities such as discounting \%35 for Peshmerga, poor's family. In addition constructing a mosque and a hall which is free for NGO to make their activities plus some activities for awareness people through the sickness with gave the foods for people as free.

\section{Conclusions}

There has the insignificant effect of CSR activities on job satisfaction of employees in Paky hospital; as well all of the elements or activities of CSR and job satisfaction are common in the hospital.

The most attractive activities of CSR are expressing the important of the CSR. In addition, the inferior elements are the employees aware of the CSR at the hospital. However, according to interviews directed to the relevant managers of Paky Hospital is most of managers have a positive expression with responsibility for providing the wellbeing of the society customers, at the same time, according to the CSR activities the manager's focus on Paky card of the health insurance. Correspondingly, according to managers talks they are spent thousands of US $\$$ to the CSR activities, in addition, some of the manager feel that CSR programs has a positive impact on profits, but others do not reflect. As well as some of managers think that the social responsibility program has an effect on marketing; also others believe it has an impact on this excellently, lastly all managers think that the employees of Paky are aware CSR activities.

On the other hands, there is some information at 2017 that concentrated on CSR activities such as discounting \%35 for Peshmerga, poor's family. In addition constructing a mosque and a hall which is free for NGO to make their activities plus some activities for awareness people through the sickness with gave the foods for people as open.

\section{Recommendations}

Through the study conclusions researchers are suggested that:

Paky's hospital should perform to CSR activities inorderto rise job satisfaction toward employees. And it is possible to spend amount of money to increasing awareness and responsibility for providing the well-being of the community customers, as well as it is necessary to focus the manager on the Paky card of health insurance. In addition, it should to spending moneys on CSR activities, especially for Peshmargs and poor families. Generally companies are required to provide CSR programs to positively affect the profits and returns. 


\section{References}

[1] Boswell, W.R., Shipp, A.J., Payne, S.C., \& Culbertson, S.S. (2009). Changes in employee job change and job satisfaction: The honeymoon hangover effect, and procedural justice on correctional staff job stress, job satisfaction, and moderate the relationship between intrinsic job satisfaction and voluntary.

[2] Çelik, M. (2011) A theoretical approach to the job satisfaction, Polish journal of management studies, Vol. 4.

[3] Hakansson, F., O’Neill, E. (2016) "Impact of corporate social responsibility (CSR) reporting and communicating on employee commitment: a local Iswedich perspective", Master theses at Karlstad Business School, Karlstad University.

[4] Hameed, S. K. (2010)" Corporate Social Responsibility (CSR) Theory and Practice in Pakistan", Master's thesis at Swedish University of Agricultural Sciences, Online publication: http://stud.epsilon.slu.se

[5] Macuda, M. (2016) "Corporate Social Responsibility-A new trend in hospital accounting", Studia Ekonomiczne. Zeszyty Naukowe, Uniwersytetu Ekonomicznego w Katowicach, ISSN 2083-8611.

[6] Neog, B. B. and Barua, M. (2014) factors influencing employee's job satisfaction,
The SIJ Transactions on Industrial, Financial \& Business Management (IFBM), Vol. 2, No. 7.

[7] Shareef, V. A., Husien, A. H., and Omer, S. K. (2018)" The effect of Interior design on employiees job satisfaction", (JPMNT) Journal of Process Management - New Technologies, International, Vol. 6, No. 2.

[8] Shuli, G. and Suwandee, S. (2017)" Effect of corporate social responsibility on employee job performance: A case study of household products manufacturers in southern China", Journal of Thai Interdisciplinary Research, Vol.12, No. 5, Pp. $57-63$.

[9] Smith, E. R. (2011) “ Defining Corporate Social Responsibility: A systems approach for socially responsible capitalism", Master theses at University of Pennsylvania.

[10] Walker, A. and Sorce, P. (2009) correlates of job satisfaction of early career employees in printing and publishing occupations, Printing Industry Center at RIT Rochester, NY.

[11] Yapar, A. (2017) "The Effect of Corporate Social Responsibility on Employee Satisfaction and Loyalty: A research on Turkish Employees", International Research Journal of Interdisciplinary \& Multidisciplinary Studies (IRJIMS), Vol. 3, No. 1, Pp. 87-105, ISSN: 2394-7969, Website: http://www.irjims.com 